\title{
Fate of Microplastics in the Marine Isopod Idotea emarginata
}

\author{
Julia Hämer, ${ }^{\dagger \dagger}$ Lars Gutow, $^{\dagger}$ Angela Köhler, ${ }^{\dagger}$ and Reinhard Saborowski* ${ }^{\dagger}$ \\ ${ }^{\dagger}$ Helmholtz Centre for Polar and Marine Research, Alfred Wegener Institute, Am Handelshafen 12, 27570 Bremerhaven, Germany \\ ${ }^{\ddagger}$ Department of Ecology, Evolution and Biodiversity, Ruhr University Bochum, 44780 Bochum, Germany
}

\section{Supporting Information}

ABSTRACT: Plastic pollution is an emerging global threat for marine wildlife. Many species of birds, reptiles, and fishes are directly impaired by plastics as they can get entangled in ropes and drown or they can ingest plastic fragments which, in turn, may clog their stomachs and guts. Microplastics of less than 1 $\mathrm{mm}$ can be ingested by small invertebrates, but their fate in the digestive organs and their effects on the animals are yet not well understood. We embedded fluorescent microplastics in artificial agarose-based food and offered the food to marine isopods, Idotea emarginata. The isopods did not distinguish between food with and food without microplastics. Upon ingestion, the microplastics were present in the stomach and in the gut but not in the tubules of the midgut gland which is the

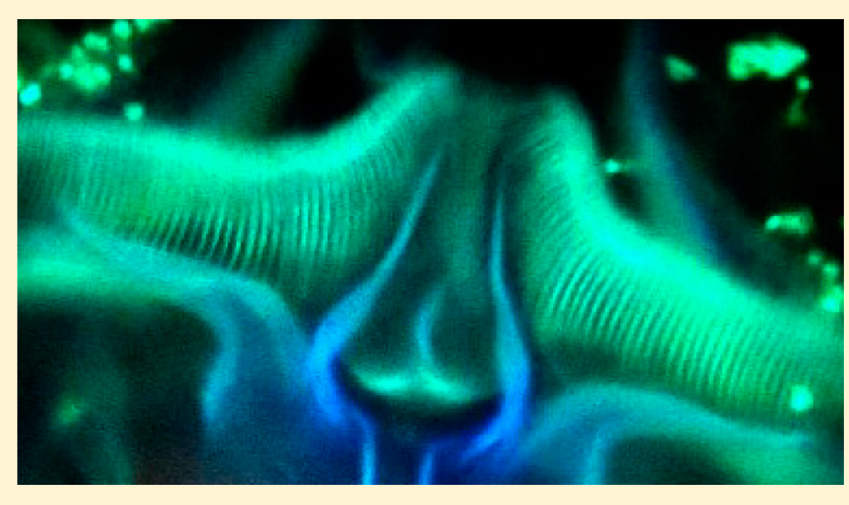
principal organ of enzyme-secretion and nutrient resorption. The feces contained the same concentration of microplastics as the food which indicates that no accumulation of microplastics happens during the gut passage. Long-term bioassays of 6 weeks showed no distinct effects of continuous microplastic consumption on mortality, growth, and intermolt duration. I. emarginata are able to prevent intrusion of particles even smaller than $1 \mu \mathrm{m}$ into the midgut gland which is facilitated by the complex structure of the stomach including a fine filter system. It separates the midgut gland tubules from the stomach and allows only the passage of fluids and chyme. Our results indicate that microplastics, as administered in the experiments, do not clog the digestive organs of isopods and do not have adverse effects on their life history parameters.

\section{INTRODUCTION}

Continuously increasing production and utilization of plastic products cause serious global pollution problems. ${ }^{1,2}$ Plastics are hard to degrade. ${ }^{3}$ Therefore, they accumulate in the environment and, particularly, in the oceans where they became the dominant share of the marine debris ${ }^{2,4-7}$ Depending on size and shape marine plastic litter can adversely affect a variety of organisms. ${ }^{1,6,8,9}$ The most obvious and immediate threat of plastic litter for marine wildlife is entanglement and strangulation. Not less harmful is the ingestion of plastic items as these can clog or injure the stomachs of fishes and birds and kill these animals. ${ }^{1,2,6,10-13}$

UV-radiation and mechanical abrasion degrade plastic items into very small pieces referred to as microplastics. ${ }^{14}$ Small plastic fibers such as nylon filaments from breaking nets, ropes, or clothing are the prevalent class of microplastics in the sea followed by irregularly shaped plastic fragments, granules, and films. ${ }^{5,15-17}$ The most abundant polymer types are polyethylene, polypropylene, and polystyrene (styrofoam). ${ }^{15}$ The majority of microplastics in pelagic and benthic habitats is within the size range of 30 to $1,000 \mu \mathrm{m},{ }^{15,18,19}$ but even smaller particles were detected. ${ }^{5,20-22}$ Reported concentrations of microplastics in subtidal marine habitats range from 3.7 particles $\cdot \mathrm{kg}^{-1}$ to 124 particles $\cdot \mathrm{L}^{-1}$ of sediment. ${ }^{5,17,23}$

Due to their size microplastics can be ingested by a wide range of organisms including fish larvae and small invertebrates which, in turn, are a food source for many other marine organisms. $^{5,7,9,24}$ At least 32 marine invertebrate species including pelagic (e.g., copepods and euphausids) and benthic representatives (e.g., mussels, lobsters, and polychaetes) have been reported to ingest microplastics. ${ }^{24-27}$ Similar to larger animals, small invertebrates may suffer from clogging of digestive organs, reduced appetite, and incorporation of microplastics into body tissue. ${ }^{9,20,25,27,28}$

The effects of ingested microplastics on invertebrates are not consistent and predictable because many marine taxa are adapted to ingest nonfood particles such as sediment grains, spicules, or diatom frustules. ${ }^{29-31}$ Marine species exhibit diverse mechanisms to select, dispose, or pass indigestible materials unimpaired. ${ }^{28,32}$ Therefore, a reliable interpretation and risk assessment of the biological effects of microplastics in marine ecosystems is hampered by the poor knowledge about their fate and impacts in many animal taxa. Particularly, understanding of the effects of ingested microplastics on species of lower trophic levels is scarce. $3,9,20$

The present study aims at investigating how marine isopods cope with ingested microplastics. We chose Idotea emarginata

Received: March 25, 2014

Revised: August 6, 2014

Accepted: October 7, 2014

Published: October 7, 2014 
(Fabricius, 1793) as model species because it represents the large group of marine isopods from sub- and eulitoral habitats. It is common in temperate coastal regions of the Northeast Atlantic and predominantly associated with macroalgal debris on the sea bed. ${ }^{33}$ It is also common on floating macroalgae which accumulate frequently with flotsam in convergence zones of surface fronts. ${ }^{33-37}$ I. emarginata is an omnivorous scavenger which has a broad diet that includes macroalgae, detritus, and animal remains. ${ }^{36,38}$ Due to high densities of microplastics in its habitat it is possible that the species ingests microplastics with its food.

In laboratory experiments we offered the isopods artificial food which was blended with fluorescent plastic particles. From what we know about size and composition of marine microplastics ${ }^{5,15}$ we tested polystyrene microbeads and fragments $(1-100 \mu \mathrm{m})$ as well as polyacrylic fibers of $20-2,500$ $\mu \mathrm{m}$ and studied the deposition of the particles in the digestive organs and in fecal pellets. In long-term experiments (bioassays) we evaluated the effects of chronic ingestion of large amounts of microplastics on the life history parameters survival, feeding activity, growth, and intermolt duration. We hypothesize that a) plastic particles accumulate in the digestive system of the isopods and b) that long-term consumption of indigestible microplastics reduces growth, as measured as growth increment and duration of intermolt periods.

\section{MATERIALS AND METHODS}

Origin of Animals. Marine isopods, Idotea emarginata, were collected from floating seaweed around the island of Helgoland (North Sea, $54^{\circ} 10^{\prime} \mathrm{N} 7^{\circ} 53 \mathrm{E}$ ) but were raised and maintained in batch cultures at the Alfred Wegener Institute in Bremerhaven. Aquaria with a volume of $50 \mathrm{~L}$ were run as flow through systems with natural seawater at $15{ }^{\circ} \mathrm{C}$. The animals were fed regularly with fresh macroalgae (Fucus vesiculosus).

Fluorescent Microparticles. Three different kinds of microplastic preparations were used to trace the microscopic particles in the digestive tract of Idotea emarginata: commercial microbeads, plastic fragments, and plastic fibers. Each of these preparations consisted of fluorescent particles which allowed for a microscopic identification of administered items. The specific fluorescent properties also enabled a clear distinction from other environmental plastic contaminants. Detailed information about the sources and characteristics of the microplastic preparations is presented in the Supporting Information.

Microplastic-Supplemented Food. Artificial agar-based food was prepared with defined amounts of seaweed powder and supplements of microparticles. The standard food preparation $^{39}$ contained $0.9 \mathrm{~g}$ of freeze-dried and pestled fine powder of Fucus vesiculosus, which was suspended in $3.5 \mathrm{~mL}$ of demineralized water (aqua dem.). Defined amounts of microplastics were added to the Fucus-suspension. Depending on the purpose of the experiment the supplemented food contained low or high concentrations of particles. These were 12 or 120 microbeads per mg and 20 or 350 PE-fragments per $\mathrm{mg}$, respectively. The concentration of fibers was always $0.3 \mathrm{mg}$ per gram of food. The plastic fibers could not be homogeneously suspended in water for counting. Therefore, the amount of plastic fibers used in the experiments is given by weight and not by numbers (see the Supporting Information). Agarose (0.12 g, Sigma-Aldrich A 4679) was mixed with $7.5 \mathrm{~mL}$ of aqua dem. and heated in a microwave oven until boiling ( $\sim 5$ s). The hot agarose was added to the Fucus-suspension and stirred continuously until homogeneity. The melted agarose mixture was evenly poured onto a Petri dish to a thin layer of ca. $1.5 \mathrm{~mm}$. The agarose polymerized almost immediately, and the algal powder and the different microplastics were embedded and homogeneously dispersed in the agar food preparations. Pieces of ca. $2-4 \mathrm{~cm}^{2}$ were cut off this layer and offered as food to each isopod in the experiments.

Experimental Setup. All experiments were carried out at $13{ }^{\circ} \mathrm{C}$ and at a light:dark cycle of 12:12 h. The animals were maintained individually in $100 \mathrm{~mL}$ plastic vials filled with 60$70 \mathrm{~mL}$ of natural seawater. The water was exchanged daily. Every day at the same time during the experiments survival and molts were scored in each replicate.

Food Choice Experiments. Food choice assays were carried out to test whether the isopods distinguish between microplastic-supplemented and nonsupplemented food. I. emarginata (body length: 9-11 mm, wet weight = w.w.: $20-$ $50 \mathrm{mg}$ ) were maintained individually for 3 days and fed with two pieces of artificial food. One of these pieces contained either microbeads (at high and low concentration), fragments, or fibers. The other piece contained only algal powder without microplastics. The two pieces of food were tagged with differently colored cotton strings (ca. $1 \mathrm{~cm}$ long). Each feeding experiment was run with 24 individuals. Another five or six vials contained one piece of each food type in seawater without isopod to determine autogenic changes of weight of the food due to soaking or leaching. The offered food was weighed (w.w., precision: $0.1 \mathrm{mg}$ ) at the beginning and at the end of the feeding experiment and corrected for the average autogenous weight change, and the specific feeding rate was calculated in relation to the individual wet weight of the animals and expressed as mg food per mg animal weight and day. ${ }^{40}$ The equations are presented in the Supporting Information.

Localization of Microparticles in the Digestive Tract. Histological analyses were conducted to investigate the distribution of microplastics within the digestive tract of $I$. emarginata. Juvenile isopods (body length: $8-10 \mathrm{~mm}$ ) were maintained individually in $100 \mathrm{~mL}$ plastic vials as described above and fed for 3 days food with high concentrations of microbeads $\left(\sim 120\right.$ particles $\left.\cdot \mathrm{mg}_{\text {food }}{ }^{-1}\right)$, fragments ( 350 particles $\left.\cdot \mathrm{mg}_{\text {food }}{ }^{-1}\right)$, and fibers $\left(0.3 \mathrm{mg} \cdot \mathrm{g}_{\text {food }}{ }^{-1}\right)$, respectively. Animals selected for histological studies were carefully blotted dry on paper tissue, stretched straight, and frozen with liquid nitrogen $\left(-196{ }^{\circ} \mathrm{C}\right)$. The frozen animals were stored at -80 ${ }^{\circ} \mathrm{C}$. For the preparation of histological cryo-sections $(20 \mu \mathrm{m})$ whole frozen animals or parts thereof were mounted on a microtome stage (chuck) with a cryogenic medium (NEG $50^{\mathrm{Tm}}$, Thermo Scientific Richard Allan Scientific). The samples were sliced longitudinally or transversally in a cryo-microtome (Microm HM $500 \mathrm{OM}$ ) at $-23{ }^{\circ} \mathrm{C}$. Frozen slices were transferred onto microscopy glass slides and dried at room temperature for ca. $3 \mathrm{~min}$. The slices were neither fixed nor stained. They were mounted in Kaiser's glycerol gelatin (ca. 70 ${ }^{\circ} \mathrm{C}$ ), dried, and stored in the dark at room temperature. Microscopy was performed with a Nikon Multizoom AZ100 fluorescence microscope equipped with a $1 \times, 2 \times$, and $5 \times$ lens and related zoom stages $(1-8)$. The fluorescent particles were detected with the Nikon filter devices B-2A (Ex. 450-490 nm) and UV-2A (Ex. 330-380) and photographed with a Nikon camera DS-Ril and related NIS-software.

Quantification of Microparticles in the Digestive Tract. The numbers of microplastics were quantified in the major organs of the digestive system of I. emarginata as well as 
in the food and in the feces. First, three groups of ten adult isopods each (body length: 15-20 mm) were fed for 3 days with one of the three artificial feeds $(\sim 120$ microbeads. $\mathrm{mg}_{\text {food }}{ }^{-1}, \sim 350$ fragments $\cdot \mathrm{mg}_{\text {food }}{ }^{-1}$, or $0.3 \mathrm{mg}$ fibers $\left.\cdot \mathrm{g}_{\text {food }}{ }^{-1}\right)$. After feeding, the isopods were frozen with liquid nitrogen. The digestive tract was dissected from the frozen animals and separated into the proventriculus (stomach), the midgut diverticula (midgut glands), and the gut. The dissected organs were transferred into $2 \mathrm{~mL}$ reaction cups, weighed (w.w.), and homogenized in $1.5 \mathrm{~mL}$ of aqua dem. with a micropestle. Pieces of the foods offered during the experiment and the feces of each individual (ca. $10 \mathrm{mg}$ w.w.) which were released during the feeding period were collected and homogenized as well. Microplastics were counted in a Sedgewick-Rafter counting cell under a fluorescence binocular (Nikon Multizoom AZ100).

Long-Term Bioassays. Long-term experiments were conducted to assess potential effects of chronic (6-7 weeks) ingestion of microplastics on the vitality, intermolt duration, size increment, and ingestion rate of juvenile I. emarginata. Details are given in the Supporting Information.

Scanning Electron Microscopy (SEM). SEM of stomachs of I. emarginata was carried out to study the internal ultrastructure of the organ. Stomachs were carefully dissected from deep frozen animals from the batch cultures which were not fed with microplastics. Connective tissue surrounding the stomach was removed by soaking the organ overnight in a mild detergent solution. Subsequently, the stomachs were rinsed with distilled water and dehydrated in an ethanol-series: $2 \times 15$ min 50\% ethanol, $2 \times 15 \mathrm{~min} 70 \%$ ethanol, $2 \times 15 \mathrm{~min}$ in $90 \%$ ethanol, $2 \times 15 \mathrm{~min}$ in $100 \%$ ethanol, $1 \times 30 \mathrm{~min}$ in ethanol:hexamethyldisilazane (HMDS) solution (1:1 vol) and finally incubated for $60 \mathrm{~min}$ in pure HMDS. The organs were then air-dried and mounted on SEM stubs with double sided carbon tape and sputter coated with gold/paladium. The proventricular structures were examined with a Quanta 3D 200 (FEI) scanning electron microscope and the related documentation module.

Data Analysis. Food choice assays: Individuals which did not eat due to molting (max. two within one food choice assay) were excluded from the statistical analysis. The effect of food quality (microplastics vs no microplastics) on the per capita ingestion rates of the isopods was analyzed for each artificial food type (containing microbeads, fibers, or fragments) separately by a $t$ test after an F-test for homogeneity of variances. ${ }^{40}$ Variance heterogeneity revealed by the F-test could be ignored as the subsequent $t$ test did not reveal any effect of food quality on the consumption rates. The results were presented as daily ingestion rate ( $\mathrm{mg}$ of food) per $\mathrm{mg}$ body weight $\left(\mathrm{mg}_{\mathrm{f}} \mathrm{mg}_{\mathrm{bw}}{ }^{-1} \cdot \mathrm{d}^{-1}\right)$.

Quantification of Microplastics. The concentrations of particles within different sections of the digestive tract were mutually dependent. Therefore, the nonparametric Friedman test was applied to test for differences in particle concentrations among the food, the organs, and the feces based on a significance level of $\alpha=0.05$. Subsequently, Dunn's multiple comparison test was performed for posthoc pairwise comparisons of particle concentrations in the food, the different sections of the digestive tract, and in the fecal pellets. Friedman test and Dunn's test were performed with the software package GraphPad Prism Version 5.04 (GraphPad Software Inc., La Jolla, CA).

Bioassays. The results of the bioassays were analyzed by one-factorial Analyses of Variance (ANOVA) and repeated measures ANOVA (rm-ANOVA) as described in detail in the Supporting Information. The tests were performed with the software package Statistica Version 7.1 (StatSoft Inc., Tulsa, $\mathrm{OK})$. The results are presented in the text and in the graphs as means and standard error of the mean (SEM).

\section{RESULTS}

Food Choice Experiments. Idotea emarginata readily fed on all food preparations and did not distinguish between artificial food with and without microplastics irrespective of whether the microplastics were microbeads at different concentrations (12 or 120 per $\mathrm{mg}$ ), fragments, or fibers (Figure 1, each $p>0.05$. Microbeads low concentration: $t=$

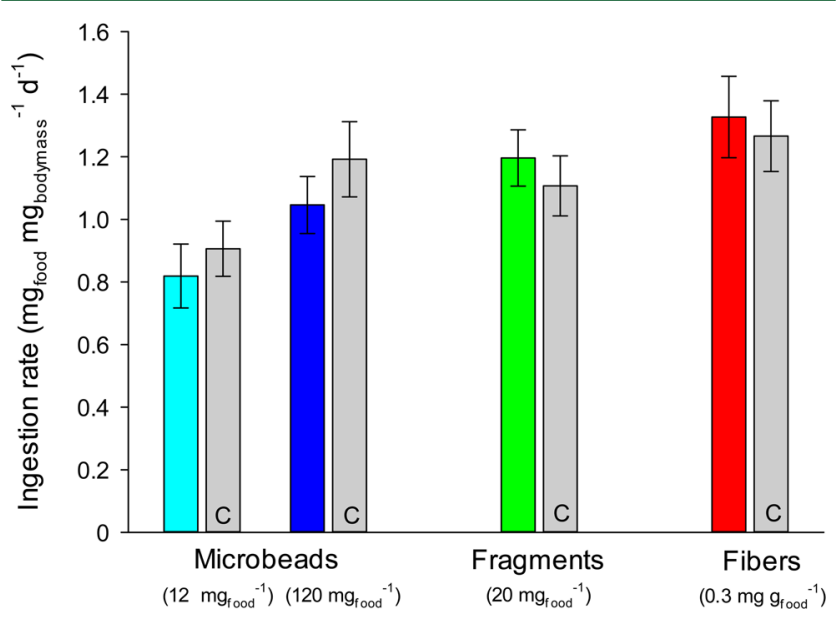

Figure 1. Ingestion rates of artificial agar based food by Idotea emarginata. The food contained different concentrations of microbeads, fragments, and fibers. Control food (C) contained agar based food without microplastics. Means \pm SEM, $n=22-24$.

$0.11 ; \mathrm{df}=27 ; p=0.91$. Microbeads high concentration: $t=$ $0.55 ; \mathrm{df}=28 ; p=0.59$. Fragments: $t=0.43 ; \mathrm{df}=25 ; p=0.67$. Fibers: $t=0.87$; $\mathrm{df}=27 ; p=0.39$.). All isopods survived the food choice experiments. However, two specimens fed with microbeads (12 per $\mathrm{mg}$ ), one specimen fed with fragments and one specimen fed with fibers did not eat due to molting. The average consumption rates for the control food without microplastics ranged from $0.82 \pm 0.10 \mathrm{mg}_{\mathrm{f}} \mathrm{mg}_{\mathrm{bm}}{ }^{-1} \cdot \mathrm{d}^{-1}(\mathrm{mg}$ food per mg body mass and day) to $1.33 \pm 0.13 \mathrm{mg}_{\mathrm{f}} \cdot \mathrm{mg}_{\mathrm{bm}}{ }^{-1}$. $\mathrm{d}^{-1}$. The average consumption rates for the artificial food containing microplastics varied between $0.91 \pm 0.09 \mathrm{mg}_{\mathrm{f}}$ $\mathrm{mg}_{\mathrm{bm}}{ }^{-1} \cdot \mathrm{d}^{-1}$ for food with 12 microbeads per $\mathrm{mg}_{\mathrm{f}}$ and $1.33 \pm$ $0.63 \mathrm{mg}_{\mathrm{f}} \mathrm{mg}_{\mathrm{bw}}{ }^{-1} \cdot \mathrm{d}^{-1}$ for food with fibers.

Observation of Microparticles in the Digestive Tract. Low numbers of microbeads were observed in the stomachs, whereas high numbers of microbeads were found in the guts. However, none of the cryosections displayed microbeads in the midgut glands (Figure $2 \mathrm{a}-\mathrm{c}$ ). Similar to the microbeads, plastic fragments were also rarely observed in the stomachs of the isopods, whereas fragments were abundant in the guts. Again, the midgut gland tubules were void of microplastic fragments in all observed individuals. Fibers were present in the stomachs and guts of each of the observed isopods. None of the cryosections displayed fibers in the midgut glands. The ingested microbeads, fragments, and fibers were homogeneously dispersed within the ingested food mass along the gut. No conspicuous aggregation of particles was observed. 

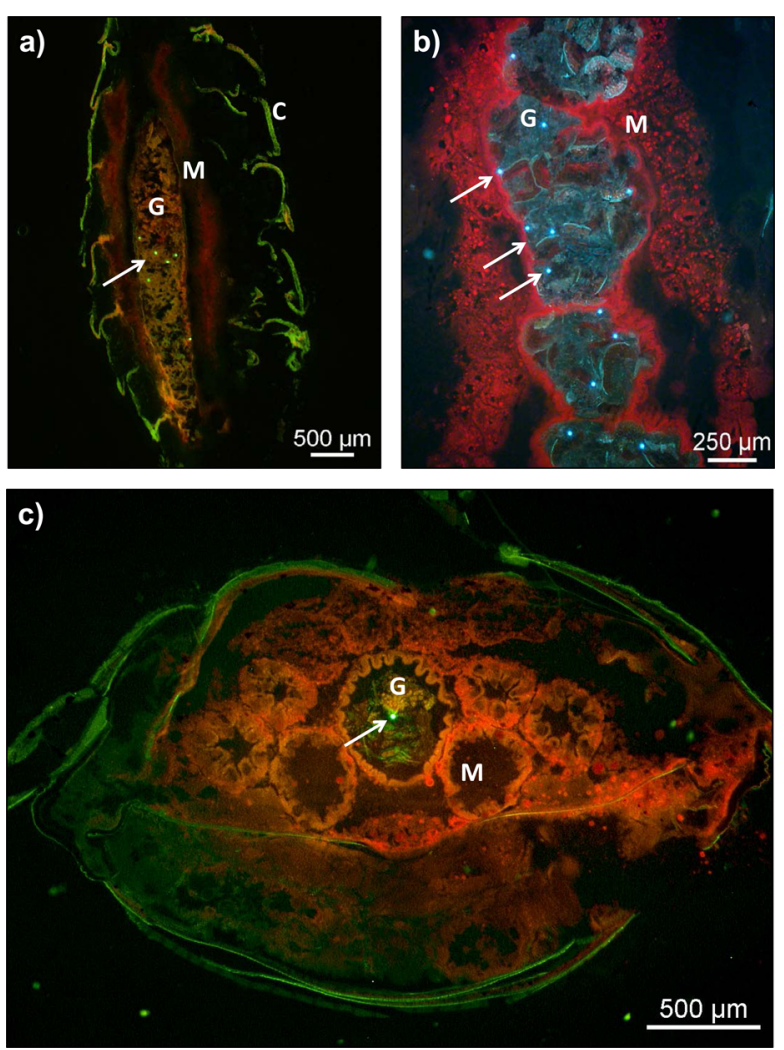

Figure 2. Fluorescence images of whole mount cryosections of Idotea emarginata. a) Overview on digestive organs and gut containing microbeads. b) Detailed view on microbeads in the gut. No microbeads were present in the midgut gland. c) Transveral slice through the gut with a microplastic particle and the six midgut gland tubules void of microplastics. ( $\mathrm{C}=$ cuticle, $\mathrm{G}=$ gut, $\mathrm{M}=$ midgut gland, arrows indicate microbeads).

Quantification of Microparticles. The distribution of microplastic particles was significantly nonrandom among all compartments (range of Friedman statistic: 27.8-32.5; $p<$ 0.001 for each type of microplastics) but similar among the different plastic sources (Figure 3). On average, less than 1 to about 3.5 microplastic particles were detected per $\mathrm{mg}$ stomach tissue. Only one single microbead and one single fragment were detected in two out of 28 midgut gland samples. Within the digestive tract, the amount of microplastics was always highest in the gut yielding on average $66 \pm 22$ microbeads (Figure 3a) and $90 \pm 21$ fragments (Figure $3 \mathrm{~b}$ ) per $\mathrm{mg}$ gut tissue. Isopods fed with fibers displayed on average less than one fiber per mg gut tissue (Figure 3c). One gut homogenate contained six fibers. The concentration of microplastics in the fecal pellets was on average $130 \pm 15$ microbeads and $369 \pm 79$ fragments per mg. These values were in the same range as the particle concentration in the food $(112 \pm 14$ microbeads per $\mathrm{mg}$ and $361 \pm 73$ fragments per mg; Dunn's multiple comparison test: $p>0.05$ for each type of microplastics). Likewise, the concentration of fibers was similar in the food $(1.6 \pm 0.3$ fibers per $\mathrm{mg})$ and in the feces $(1.2 \pm 0.2$ fibers per mg; Dunn's multiple comparison test: $p>0.05)$.

Long-Term Bioassays. The ingestion rates of isopods feeding on artificial food with different microplastics and without microplastics varied substantially during the 6 week bioassay. Supplement of microplastics had no distinct effect on life history parameters of the isopods. Detailed results of the experiment are presented in the Supporting Information.
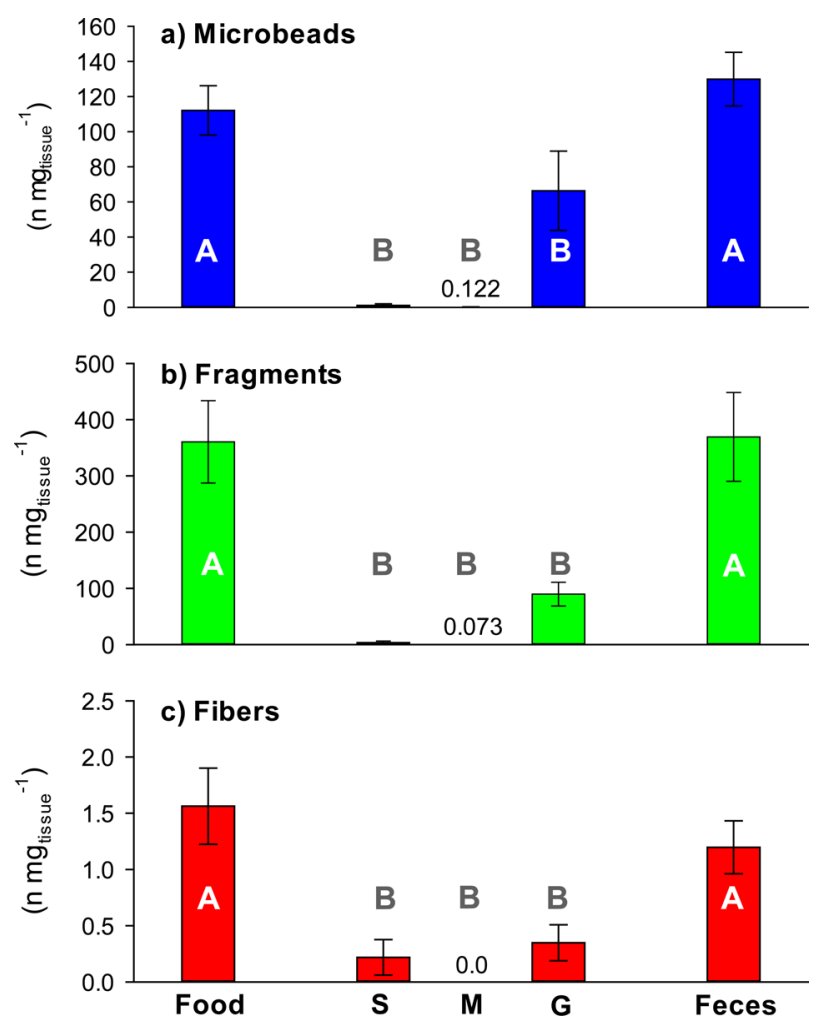

Figure 3. Concentrations of a) microbeads, b) fragments, and c) fibers in the food, the digestive organs ( $\mathrm{S}=$ stomach, $\mathrm{M}=$ midgut gland, $\mathrm{G}=$ gut) and in the feces of isopods, I. emarginata. Means \pm SEM, $n=9-$ 10. When bars were too small, numbers were provided in addition. Different letters $(\mathrm{A}, \mathrm{B})$ indicate statistically different values $(p<0.05)$.

Ultrastructure of the Stomach. The stomach of isopods bears a complex triturating system including ossicles, spines, and ridges (Figure 4). It performs the mastication of the food. ${ }^{36,42}$ A paired bristle plate in the anterior part (cardia) of the stomach forms the primary filter (F1). The gaps between the setae of the primary filter are in the size range of only a few $\mu \mathrm{m}$. The posterior part of the stomach (pylorus) includes another prominent filter apparatus, the secondary filter (F2), which consists of various lamellae and setose structures. The secondary filter covers the connection to the ventrally arising midgut gland tubules. ${ }^{44,45}$ The gaps between the filtering setae are about $1 \mu \mathrm{m}$ or smaller. As reported for other crustacean species it allows the passage of particles $<1.2 \mu \mathrm{m}^{43-48}$ into the midgut gland, which is the principal organ where the secretion of digestive enzyme and the absorption of nutrients happens. ${ }^{4,49,50}$ More details about the function and the ultrastructure of the digestive system of isopods are provided in the Supporting Information.

\section{DISCUSSION}

Our results indicate that the ingestion of microplastics has no negative impact on the marine isopod Idotea emarginata. The isopods ingested microplastic particles $(1-100 \mu \mathrm{m})$ and fibers $(20-2,500 \mu \mathrm{m})$ with the food. Microparticles and fibers appeared in the stomach and in the gut but were continuously egested. None of the different types of microplastics accumulated in the stomach or were transferred into the tubules of the midgut gland, the principal site where the particles could be absorbed. Moreover, chronic ingestion of microplastics had no distinct adverse effects on survival, 

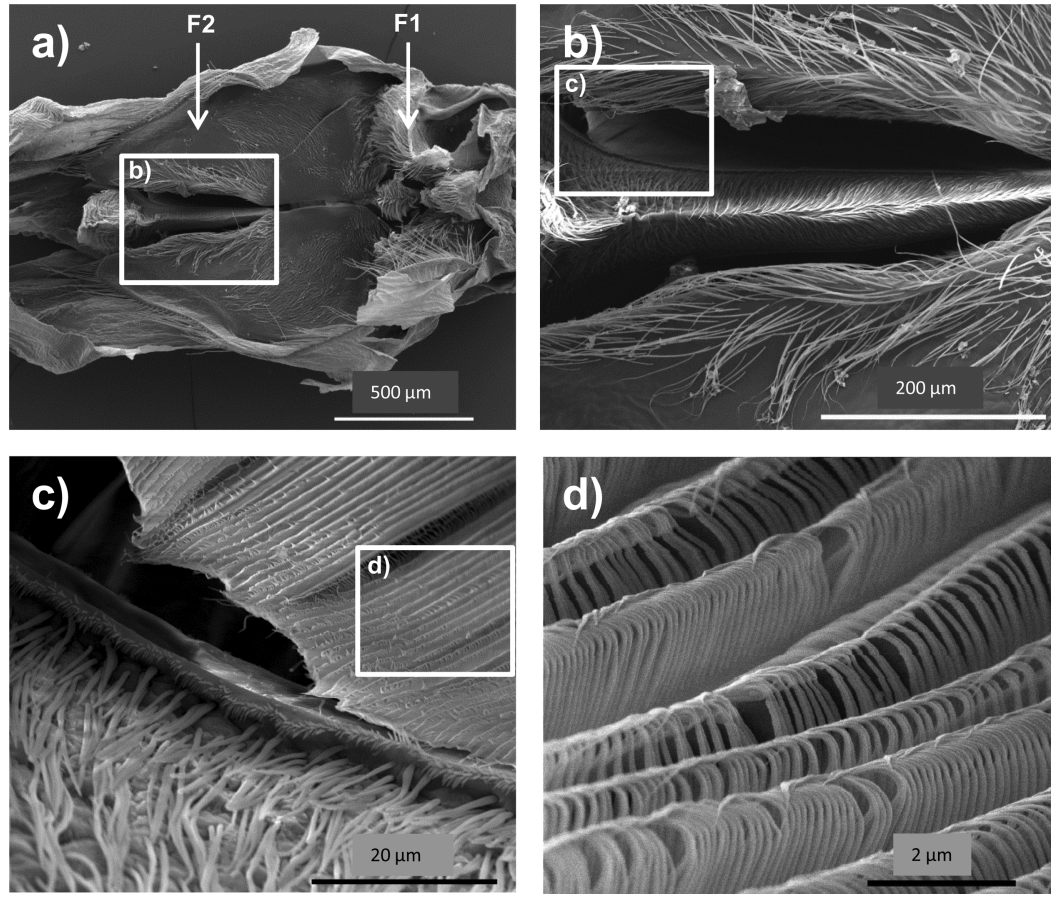

Figure 4. Scanning electron micrographs of the stomach of Idotea emarginata. a) Dorsal view on the opened stomach showing the primary filter (F1) and the secondary filter (F2). b) Secondary filter apparatus in the pyloric chamber. c, d) Details of the setose structures of the fine-meshed secondary filter.

intermolt duration, and growth of the isopods (also see the Supporting Information).

I. emarginata did not distinguish between food supplemented with microplastics and food without microplastics, even when present at very high concentrations of 120 particles per mg food. Nonselective ingestion of microplastics smaller than 100 $\mu \mathrm{m}$ has been reported for several marine species with different feeding modes including the filter-feeding mussel Mytilus edulis, the deposit feeding lugworm Arenicola marina, suspensionfeeding benthic holothurians, echinoderm larvae, and various zooplankton species. ${ }^{5,9,24-26,51-54}$ Nonselective uptake of microplastics was also demonstrated for a decapod crustacean, the Norway lobster Nephrops norvegicus. Feeding experiments in the laboratory showed that all of the maintained lobsters had ingested microplastic fibers that were supplemented to the offered food. ${ }^{55}$ Moreover, field studies revealed that $83 \%$ of Norway lobsters captured from the Scottish Clyde Sea contained microplastic fibers in their stomachs, which proves that the lobsters do ingest microplastics under natural conditions. A similar process of feeding and concomitant uptake of adherent microplastics is likely for marine isopods as well because microplastics constitute an omnipresent pollutant in their habitats. Various studies demonstrated the presence of microplastics in the North Sea with maximum concentrations of up to 86 fibers $\cdot \mathrm{kg}^{-1}$ sediment (dry weight) in subtidal habitats. 5,9,17-19,21,22 Especially zones of low hydrodynamic action or dense macroalgal cover can reduce the water turbulence and thereby enhance deposition and sedimentation of particulate matter. ${ }^{15,56}$ Additionally, Fucus canopies create a complex surface where plastic particles and fibers could stick to or get trapped. Accordingly, it is very likely that microplastics are closely associated with the natural food of I. emarginata and, thus, can be ingested by the isopods.

The microplastics displayed a clear distribution pattern in the alimentary tract of I. emarginata. Microplastics of each of the administered type were detected in the stomach, the gut, and in the feces. The concentrations of microparticles in the food and in the feces were similar, indicating that no retention or accumulation of microparticles happens during the gut passage. The concentrations of microparticles were lower in the stomach than in the food. This can be explained by the anatomy of the stomach. The dissected stomach consists of a chitinous capsule and surrounding connective tissue and muscle tissue. Thus, the weight of the organ is quite high compared to the weight of the content of the stomach which, consequently, yields a low specific particle concentration. The same effect is valid for the gut which, however, shows a higher weight ratio between the content and the organ. In contrast to the stomach and the gut, no microparticles were present within the midgut gland tubules as indicated by the histological slices. Only two out of 28 midgut gland samples contained one single microparticle. These cases may be handling artifacts caused by crosscontamination of tissues during the dissection of the tiny organs and subsequent preparation of the homogenates. Our findings are in accordance with recent laboratory studies on zooplankton species from the northeast Atlantic. The uptake of microplastics (1.4 to $30.6 \mu \mathrm{m}$ ) in copepods and other zooplankton was examined. ${ }^{27,54}$ Ingested particles were transferred into the midgut and the hindgut from where the plastics were egested in fecal pellets after a few hours. Gut clearance experiments on grass shrimps, Palaemonetes pugio, likewise, displayed the absence of microbeads $(2-4 \mu \mathrm{m})$ in the digestive glands of all animals. ${ }^{57}$ Microbeads were quickly transferred from the esophagus into the proventriculus and further passed through the hindgut, as it was shown in our study for $I$. emarginata. Moreover, the microplastics were homogeneously dispersed within the stomach and hindgut of all specimens. There was no evidence for aggregation or blockage of organs or for the abrasion or infraction of internal tissues. 
Apparently, the unique organization of the digestive organs and, particularly, the complex anatomy and function of the isopod stomach is the reason for the absence of microplastics in the tubules of the midgut gland. ${ }^{41,45,57}$ Isopods possess strong chitinous mouthparts which are well adapted for the indiscriminate ingestion of large food masses. ${ }^{36}$ The food passes unhindered through a short esophagus into the stomach. There, sclerotized structures in the anterior stomach chamber grind and crush the ingested food material and mix it with digestive enzymes to a chyme which is then passed toward the digestive tubules. ${ }^{36,41,45}$ Fine-meshed filters in the anterior stomach prevent particles from entering the midgut gland tubules. ${ }^{41,45}$ Hence, this mechanism hinders the passage of particles into the digestive glands. These are the most likely, if not only, sites where microparticles may enter the cells via pino- or phagocytosis. The remaining indigestible food mass is passed into the hindgut and egested as feces. Moreover, isopods produce peritrophic membranes in their hindgut. These peritrophic membranes consist of a very fine-meshed (nmrange) net of chitinous fibers. They enclose the food remains forming so-called fecal pellets or fecal strings. ${ }^{58,59}$ The peritrophic membrane separates the food remains from the gut epithelia and, thus, prevents the mechanical infraction of the sensitive epithelia by sharp fragments. Moreover, the peritrophic membranes assemble and concentrate the food remains within the fecal strings and accelerate the evacuation of the gut. $^{49,59}$

The size retention of the gastric filters of Crustacea is commonly about $1 \mu \mathrm{m}$. Phyllosoma larvae of the spiny lobster, Sagmariasus verreauxi, for example, showed a fully functional filter press already in the early larval stages. The gaps between the filter setae were $0.91 \mu \mathrm{m}$. The filter press retained more than $99 \%$ of particles larger than $1 \mu \mathrm{m}$ from entering the midgut gland but allowed passing of smaller particles. ${ }^{60}$ Trophic transfer of $0.5 \mu \mathrm{m}$ fluorescent polystyrene microspheres was observed from blue mussels, Mytilus edulis, to the shore crab, Carcinus maenas. Mussels which were exposed to high concentrations of microspheres $\left(10^{9} \mathrm{~L}^{-1}\right)$ for $1 \mathrm{~h}$ were fed to crabs. After feeding, the microspheres were detected in the stomach, in the midgut gland, and in the hemolymph of the crabs indicating uptake and, thus, trophic transfer of the microspheres into the digestive organs and body fluids of the predator. ${ }^{61}$ After 21 days, however, the microspheres were evacuated from the crab tissues and hemolymph. In our study, different types and sizes of microplastic particles were used. The microbeads of $10 \mu \mathrm{m}$ and the fibers were too large to pass the pyloric filter press of $I$. emarginata. However, the preparation of plastic fragments also contained particles smaller than $1 \mu \mathrm{m}$. Nevertheless, we could not locate those particles in the midgut gland. Probably, the isopods exhibit a higher retention of the pyloric filter than other crustaceans which, however, needs to be investigated in future experiments. Additionally, the way how microplastics are administered may affect their distribution in the body. We embedded microparticles together with powdered algae in an agarose matrix. The isopods bite off pieces from their food which, upon ingestion, are further macerated in the stomach. Depending on the efficiency of maceration the microparticles may be entirely liberated from the food matrix or they may remain attached to fragments of the matrix. In the latter case, the attached matrix material would mask the real size of the microparticles and make them appear and behave like larger particles. Accordingly, the uptake and, finally, the effects of microparticles strongly depend on the way how the particles are available in the environment and on the feeding mode, the completeness of decomposition, and the assimilation efficiency of the consumer.

In contrast to isopods, bivalves, for example, do not possess this kind of filter and separation mechanisms. In the filterfeeding blue mussel, Mytilus edulis, the capture and selection of food particles is facilitated by the gills. The ciliated labial palps and the oral groove select the filtered particles for size and chemical cues. From there the particles are either rejected as pseudofeces or transported to the mouth. ${ }^{62,63}$ Once ingested, the particles enter the stomach and the digestive tubules unobstructed and can be absorbed by the midgut gland cells. $^{64,65}$ In contrast to isopods, M. edulis showed microplastic aggregation in the gut and transfer of microparticles into the digestive tubules (hepatopancreas). ${ }^{24,25}$ Moreover, microplastics smaller than about $10 \mu \mathrm{m}$ were subsequently transferred into the circulatory system of the bivalve. ${ }^{24}$ It was also shown that microplastics $(<80 \mu \mathrm{m})$ were taken up into epithelial cells of blue mussels via endocytosis entailing toxicological responses. Aggregates of high-density PE microplastics caused inflammatory reactions in the hepatopancreas. ${ }^{25}$

We conclude that the effects of microplastics on marine organisms are not consistent among species but depend on various factors such as the size and deposition of microplastics in the environment, the availability and the feeding mode of the consumer, and, finally, the anatomy and physiology of the digestive organs. Particularly deposit and detritus feeders are well adapted to the uptake of solid nonfood particles such as sediment grains. $^{28,55}$ Ingested particulate matter could even positively contribute to the internal grinding processes of the gastric mill in Crustacea. ${ }^{66}$ Besides, the specific crustacean proventriculus with its fine-meshed filter structures seems to be an effective tool to prevent the passage of indigestible particles $>1 \mu \mathrm{m}$ into the relevant digestive organs. ${ }^{41,45,57}$ Hence, it appears that microplastics of $1-100 \mu \mathrm{m}$ in size and fibers of $20-1,500 \mu \mathrm{m}$ do not pose a mechanical threat to marine isopods. The present results, therefore, suggest that marine isopods might be less affected by microplastic pollution than other marine invertebrate species such as filter-feeding bivalves. Although our long-term assay indicated reduced uptake of food which was supplemented with microplastic, we could not detect negative effects on growth and survival of the isopods.

However, it still remains unclear if and how microplastics smaller than $1 \mu \mathrm{m}$ and larger than $1,000 \mu \mathrm{m}$ may affect marine crustaceans and thus should be an issue of interest in future experiments. It turns out that a comprehensive understanding of the effects of marine plastic litter on individuals, communities, and food webs can only be achieved after intensive studies on species from different taxa representing the entire range of living and feeding modes and also considering their external and internal anatomical peculiarities.

\section{ASSOCIATED CONTENT}

\section{S Supporting Information}

Additional information is provided including methodological details on the preparation of the microplastics, the implementation of the bioassays including statistical analysis and the detailed results of the bioassays. A terminal paragraph explains the function of the digestive system and the ultrastructure of the stomach of crustaceans and, particularly, the studied isopods. This material is available free of charge via the Internet at http://pubs.acs.org. 


\section{AUTHOR INFORMATION}

\section{Corresponding Author}

*Phone: 49-(0)471-48312220. Fax: 49-(0)471-48312220. Email: Reinhard.Saborowski@awi.de.

\section{Author Contributions}

All authors planned and designed the study and contributed equally to the preparation of the manuscript. J.H. performed the experiments and the lab work. L.G. and R.S. supervised the research, performed the statistics, and A.K. supervised the histological studies.

\section{Notes}

The authors declare no competing financial interest.

\section{ACKNOWLEDGMENTS}

We thank Dr. Christoph Hamers (Nikon Instruments) for providing the fluorescence microscope, Dr. Matthias Brenner and Ms. Sieglinde Bahns from the Köhler-Lab for support in the histological techniques, members of the CrabLab for analytical support, and Ms. Friedel Hinz for support in scanning electron microscopy.

\section{REFERENCES}

(1) Laist, D. W. Overview of the biological effects of lost and discarded plastic debris in the marine environment. Mar. Pollut. Bull. 1987, 18 (6B), 319-326.

(2) Derraik, J. G. B. The pollution of the marine environment by plastic debris: a review. Mar. Pollut. Bull. 2002, 44 (9), 842-852.

(3) Pruter, A. T. Sources, quantities and distribution of persistent plastics in the marine environment. Mar. Pollut. Bull. 1987, 18 (6), 305-310.

(4) Colton, J. B.; Burns, B. R.; Knapp, F. D. Plastic particles in surface waters of the Northwestern Atlantic. Science 1974, 185 (4150), 491497 DOI: $10.1126 /$ science.185.4150. 491.

(5) Thompson, R. C.; Olsen, Y.; Mitchell, R. P.; Davis, A.; Rowland, S. J.; John, A. W. G.; McGonigle, D.; Russell, A. E. Lost at sea: where is all the plastic? Science 2004, 304 (5672), 838 DOI: 10.1126/ science.1094559.

(6) Moore, C. J. Synthetic polymers in the marine environment: a rapidly increasing, long-term threat. Environ. Res. 2008, 108 (2), 131139 DOI: $10.1016 /$ j.envres.2008.07.025.

(7) Barnes, D. K. A; Galgani, F.; Thompson, R. C.; Barlaz, M. Accumulation and fragmentation of plastic debris in global environments. Philos. Trans. R. Soc., B 2009, 364 (1526), 1985-1998 DOI: $10.1098 /$ rstb.2008.0205.

(8) Gray, H.; Lattin, G. L.; Moore, C. J. Incidence, mass and variety of plastics ingested by the Laysan (Phoebastria immutabilis) and Blackfooted Albatrosses (P. nigripes) recovered as by-catch in the North Pacific Ocean. Mar. Pollut. Bull. 2012, 64 (10), 2190-2192 DOI: 10.1016/j.marpolbul.2012.07.053.

(9) Wright, S. L.; Thompson, R. C.; Galloway, T. S. The physical impacts of microplastics on marine organisms: a review. Environ. Pollut. 2013, 178, 483-492 DOI: 10.1016/j.envpol.2013.02.031.

(10) Gregory, M. R. Environmental implications of plastic debris in marine settings - entanglement, ingestion, smothering, hangers-on, hitch-hiking and alien invasions. Philos. Trans. R. Soc., B 2009, 364 (1526), 2013-2025 DOI: 10.1098/rstb.2008.0265.

(11) Wilcox, C.; Hardesty, B. D.; Sharples, R.; Griffin, D. A.; Lawson, T. J.; Gunn, R. Ghost net impacts on globally threatened turtles, a spatial risk analysis for northern Australia. Conserv. Lett. 2013, 6 (4), 247-254 DOI: $10.1111 /$ conl.12001.

(12) Ryan, P. G. Seabirds indicate changes in the composition of plastic litter in the Atlantic and south-western Indian Oceans. Mar. Pollut. Bull. 2008, 56 (8), 1406-1409 DOI: 10.1016/j. marpolbul.2008.05.004.

(13) Lusher, A. L.; McHugh, M.; Thompson, R. C. Occurrence of microplastics in the gastrointestinal tract of pelagic and demersal fish from the English Channel. Mar. Pollut. Bull. 2013, 67 (1-2), 94-99 DOI: 10.1016/j.marpolbul.2012.11.028.

(14) Hidalgo-Ruz, V.; Gutow, L.; Thompson, R. C.; Thiel, M. Microplastics in the marine environment: a review of the methods used for identification and quantification. Environ. Sci. Technol. 2012, 46 (20), 3060-3075 DOI: $10.1021 /$ es2031505.

(15) Vianello, A.; Boldrin, A.; Guerriero, P.; Moschino, V.; Rella, R.; Sturaro, A.; Da Ros, L. Microplastic particles in sediments of Lagoon of Venice, Italy: first observations on occurrence, spatial patterns and identification. Estuarine, Coastal Shelf Sci. 2013, 130, 54-61 DOI: 10.1016/j.ecss.2013.03.022.

(16) Buchanan, J. B. Pollution by synthetic fibres. Mar. Pollut. Bull. 1971, 2 (2), 23.

(17) Browne, M. A.; Crump, P.; Niven, S. J.; Teuten, E.; Tonkin, A.; Galloway, T.; Thompson, R. C. Accumulation of microplastic on shorelines worldwide: sources and sinks. Environ. Sci. Technol. 2011, 45 (21), 9175-9179 DOI: 10.1021/es201811s.

(18) Moore, C. J.; Moore, S. L.; Leecaster, M. K.; Weisberg, S. B. A Comparison of plastic and plankton in the North Pacific central gyre. Mar. Pollut. Bull. 2001, 42 (12), 1297-1300.

(19) Browne, M. A.; Galloway, T.; Thompson, R. C. Microplastic - an emerging contaminant of potential concern? Integr. Environ. Assess. Manage. 2007, 3 (4), 559-561 DOI: 10.1002/ ieam.5630030412.

(20) Galgani, F.; Fleet, D.; van Franeker, F.; Katsanevakis, S.; Maes, T.; Mouat, J.; Osterbban, I.; Poitou, G.; Hanke, R.; Thompson, R.; Amato, E.; Birkun, A.; Janssen, C. Marine Strategy Framework Directive - Task Group 10 report on marine litter; European Union: Luxembourg, 2010, DOI 10.2788/86941.

(21) Andrady, A. L. Microplatics in the marine environment. Mar. Pollut. Bull. 2011, 62 (8), 1596-1605 DOI: 10.1016/j.marpolbul.2011.05.030.

(22) Ng, K. L.; Obbard, J. P. Prevalence of microplastics in Singapore's coastal marine environment. Mar. Pollut. Bull. 2006, 52 (7), 761-767 DOI: 10.1016/j.marpolbul.2005.11. 017.

(23) Claessens, M.; De Meester, S.; van Landuyt, L.; De Clerck, K.; Janssen, C. R. Occurrence and distribution of microplastics in marine sediments along the Belgian coast. Mar. Pollut. Bull. 2011, 62 (10), 2199-2204 DOI: 10.1016/j.marpolbul.2011.06.030.

(24) Browne, M. A.; Dissanayake, A.; Galloway, T. S.; Lowe, D. M.; Thompson, R. C. Ingested microscopic plastic translocates to the circulatory system of the mussel, Mytilus edulis (L.). Environ. Sci. Technol. 2008, 42 (13), 5026-5031 DOI: 1021/es800249a.

(25) von Moos, N.; Burkhardt-Holm, P.; Köhler, A. Uptake and effects of microplastics on cell and tissue of the Blue Mussel Mytilus edulis L. after an experimental exposure. Environ. Sci. Technol. 2012, 46 (20), 11327-11335 DOI: 10.1021/es302332w.

(26) Besseling, E.; Wegner, A.; Foekema, E. M.; van den HeuvelGreve, M. J.; Koelmans, A. A. Effects of microplastic on fitness and PCB bioaccumulation by the lugworm Arenicola marina (L.). Environ. Sci. Technol. 2013, 47 (1), 593-600 DOI: 10.1021/es302763x.

(27) Cole, M.; Lindeque, P.; Fileman, E.; Halsband, C.; Goodhead, R.; Moger, J.; Galloway, T. S. Microplastic ingestion by zooplankton. Environ. Sci. Technol. 2013, 47 (12), 6646-6655 DOI: 10.1021/ es400663f.

(28) Thompson, R. C. Plastic debris in the marine environment: consequences and solutions. Marine Nature Conservation in Europe 2006. Proceedings of the Symposium, Stralsund, BfN Skripten, 2007; Vol. 193, pp 107-116. http://www.habitatmarenatura2000.de (accessed Sept 30, 2014).

(29) Fauchald, K.; Jumars, P. A. The diet of worms: a study of polychaete feeding guilds. Oceanogr. Mar. Biol. Annu. Rev. 1979, 17, 193-284.

(30) Lopez, G. R.; Levinton, J. S. Ecology of deposit-feeding animals in marine sediments. Quart. Rev. Biol. 1987, 63 (3), 235-260.

(31) Buffan-Dubau, E.; Carman, K. R. Diel feeding behavior of meiofauna and their relationships with microalgal resources. Limnol. Oceanogr. 2000, 45 (2), 381-395.

(32) Ward, J. E.; Shumway, S. E. Separating the grain from the chaff: particle selection in suspension- and deposit-feeding bivalves. J. Exp. 
Mar. Biol. Ecol. 2004, 300 (1-2), 83-130 DOI: 10.1016/ j.jembe.2004.03.002.

(33) Franke, H.-D.; Gutow, L.; Janke, M. Flexible habitat selection and interactive habitat segregation in the marine congeners Idotea baltica and Idotea emarginata (Crustacea, Isopoda). Mar. Biol. 2007, 150 (5), 929-939 DOI: 10.1007/s00227-006-0421-2.

(34) Naylor, E. The ecological distribution of british species of Idotea (Isopoda). J. Anim. Ecol. 1955, 24 (2), 255-269.

(35) Naylor, E. The life cycle of the isopod Idotea emarginata (Fabricius). J. Anim. Ecol. 1955, 24 (2), 270-281.

(36) Naylor, E. The diet and feeding mechanism of Idotea. J. Mar. Biol. Assoc. U. K. 1955, 34 (2), 347-355.

(37) Franke, H.-D.; Janke, M. Mechanisms and consequences of intra- and interspecific interference competition in Idotea baltica (Pallas) and Idotea emarginata (Fabricius) (Crustacea: Isopoda): A laboratory study of possible proximate causes of habitat segregation. $J$. Exp. Mar. Biol. Ecol. 1998, 227 (1), 1-21 DOI: 10.1016/S00220981(97)00253-0.

(38) Schaffelke, B.; Evers, D.; Walhorn, A. Selective grazing of the isopod Idotea baltica between Fucus evanescens and F. vesiculosus from Kiel Fiord (Western Baltic). Mar. Biol. 1995, 124 (2), 215-218 DOI: 10-1007/BF00347125.

(39) Hay, M. E.; Stachowicz, J. J.; Cruz-Rivera, E.; Bullard, S.; Deal, M. S.; Lindquist, N. Bioassays with marine and freshwater organisms. In Methods in Chemical Ecology, Bioassays; Haynes, K. F., Millar, J. R., Eds.; Chapman and Hall: New York, 1998; Vol. 2; pp 39-141.

(40) Peterson, C. H.; Renaud, P. E. Analysis of feeding preference experiments. Oecologia 1989, 80 (1), 82-86 DOI: 10.1007/ BF00789935.

(41) Storch, V. Microscopic anatomy and ultrastructure of the stomach of Porcellio scaber (Crustacea, Isopoda). Zoomorphology 1987, 106 (5), 301-311.

(42) Barnard, K. H. The digestive canal of the isopod crustaeceans. Trans. R. Soc. S. Africa 1924, 12 (1), 27-36.

(43) Dall, W.; Moriarty, D. J. W. Functional aspects of nutrition and digestion. In The Biology of Crustacea. 5. Internal Anatomy and Physiological Regulation; Mantel, L. H., Ed.; Academic Press: New York, 1983; pp 215-261.

(44) McLaughlin, P. A. Comparative morphology of recent crustacea; W. H. Freeman and Company: San Francisco, 1980.

(45) Zimmer, M. Nutrition in terrestrial isopods (Isopoda: Oniscidea): an evolutionary-ecological approach. Biol. Rev. 2002, 77 (4), 455-493 DOI: $10.1017 /$ S1464793102005912.

(46) Kunze, J.; Anderson, D. T. Functional morphology of the mouthparts and gastric mill in the hermit crabs Clibanarius taeniatus (Milne Edwards), Clibanarius virescens (Krauss), Paguristes squamosus (McCulloch) and Dardanus setifer (Milne-Edwards) (Anomura: Paguridae). Mar. Freshwater Res. 1979, 30 (5), 683-722.

(47) Vogt, G. Morphology and physiology of digestive epithelia in decapod crustaceans. Pflügers Arch. 1996, 431 (S6), R239.

(48) Štrus, J.; Storch, V. Comparative electron microscopic study of the stomach of Orchestia cavimana and Arcitalitrus sylvaticus (Crustacea: Amphipoda). J. Morph. 2004, 259 (3), 340-346.

(49) Jones, D. A. The functional morphology of the digestive system in the carnivorous intertidal isopod Eurydice. J. Zool. 1968, 156 (3), 363-376 DOI: 10.1111/j.1469-7998.1968. tb04359.x.

(50) Jones, D. A.; Babbage, P. C.; King, P. E. Studies on digestion and the fine structure of digestive caeca in Eurydice pulchra (Crustacea: Isopoda). Mar. Biol. 1969, 2 (4), 311-320.

(51) Hart, M. W. Particle captures and the method of suspension feeding by echinoderm larvae. Biol. Bull. 1991, 180 (1), 12-27.

(52) Graham, E. R.; Thompson, J. T. Deposit- and suspensionfeeding sea cucumbers (Echinodermata) ingest plastic fragments. J. Exp. Mar. Biol. Ecol. 2009, 368 (1), 22-29 DOI: 10.1016/ j.jembe.2008.09.007.

(53) Kaposi, K. L.; Mos, B.; Kelaher, B. P.; Dworjanyn, S. A. Ingestion of microplastic has limited impact on a marine larva. Environ. Sci. Technol. 2014, 48 (3), 1638-1645 DOI: 10.1021/es404295e.
(54) Setälä, O.; Fleming-Lehtinen, V.; Lehtiniemi, M. Ingestion and transfer of microplastics in the planktonic food web. Environ. Pollut. 2014, 185, 77-83 DOI: 10.1016/j.envpol.2013.10.013.

(55) Murray, F.; Cowie, P. R. Plastic contamination in the decapod crustacean Nephrops norvegicus (Linnaeus, 1758). Mar. Pollut. Bull. 2011, 62 (6), 1207-1217 DOI: 10.1016/ j.marpolbul.2011.03.032.

(56) Ward, L. G.; Kemp, W. M.; Boynton, W. R. The influence of waves and seagrass communities on suspended particulates in an estuarine embayment. Mar. Geol. 1984, 59 (1-4), 85-103.

(57) Hoyt, M.; Fleeger, J. W.; Siebeling, R.; Feller, R. J. Serological estimation of prey-protein gut-residence time and quantification of meal size for grass shrimp consuming meiofaunal copepods. J. Exp. Mar. Biol. Ecol. 2000, 248 (1), 105-119.

(58) Holdich, D. M.; Ratcliffe, N. A. A light and electron microscope study of the hindgut of the herbivorous isopod, Dynamene bidentata (Crustacea: Peracarida). Z. Zellforsch. Mikrosk. Anat. 1970, 111 (2), 209-227.

(59) Peters, W. Vorkommen, Zusammensetzung und Feinstruktur peritrophischer Membranen im Tierreich. Z. Morphol. Tiere 1968, 62 (1), 9-57.

(60) Simon, C. J.; Carter, C. G.; Battaglene, S. C. Development and function of the filter-press in spiny lobster, Sagmariasus verreauxi, phyllosoma. Aquaculture 2012, 370-371, 68-75 DOI: 10.1016/ j.aquaculture.2012.10.003.

(61) Farrell, P.; Nelson, K. Trophic level transfer of microplastic: Mytilus edulis (L.) to Carcinus maenas (L.). Environ. Pollut. 2013, 177, 1-3 DOI: 10.1016/j.envpol.2013.01.046.

(62) Beninger, P. G.; St-Jean, S. D. Particle processing on the labial palps of Mytilus edulis and Placopecten magellanicus (Mollusca, Bivalvia). Mar. Ecol. Prog. Ser. 1997, 147, 117-127 DOI: 10.3354/ meps147117.

(63) Ward, J. E.; Levinton, J. S.; Shumway, S. E.; Cucci, T. Particle sorting in bivalves: in vivo determination of the pallial organs of selection. Mar. Biol. 1998, 131 (2), 283-292.

(64) Morton, B. Feeding and digestion in Bivalvia. In The Mollusca (Vol. 5), Physiology Part 2; Wilbur, K. M., Saleuddin, A. S., Eds.; Academic Press: New York, 1983; pp 65-147.

(65) Jørgensen, C. B. Feeding and cleaning mechanisms in the suspension feeding bivalve Mytilus edulis. Mar. Biol. 1981, 65 (2), $159-163$.

(66) Carefoot, T. H. Feeding, food preference, and the uptake of food energy by the supralittoral isopod Ligia pallasii. Mar. Biol. 1973, 18 (3), 228-236. 